\title{
We are originarios...'We just aren't from here': Coca leaf and identity politics in the Chapare, Bolivia
}

Article

Accepted Version

Grisaffi, T. (2010) We are originarios...'We just aren't from here': Coca leaf and identity politics in the Chapare, Bolivia. Bulletin of Latin American Research, 29 (4). pp. 425-439. ISSN 0261-3050 doi: https://doi.org/10.1111/j.14709856.2010.00385.x Available at https://centaur.reading.ac.uk/85323/

It is advisable to refer to the publisher's version if you intend to cite from the work. See Guidance on citing.

To link to this article DOI: http://dx.doi.org/10.1111/j.1470-9856.2010.00385.x

Publisher: Wiley

All outputs in CentAUR are protected by Intellectual Property Rights law, including copyright law. Copyright and IPR is retained by the creators or other copyright holders. Terms and conditions for use of this material are defined in the End User Agreement.

www.reading.ac.uk/centaur 
Central Archive at the University of Reading

Reading's research outputs online 


\section{We Are Originarios... 'We Just Aren't From Here': Coca Leaf and Identity Politics in the Chapare, Bolivia}

\section{THOMAS GRISAFFI}

\section{London School of Economics}

This article examines the ways in which coca-leaf acquired an important symbolic value in forging a counter-hegemonic discourse that wove together various strands of class and cultural identity struggles in the Chapare province, Bolivia. The second line of enquiry that runs throughout this article deals with the conflicts that arose when the coca union mutated into a governing political party. Now that the coca grower's leader, Evo Morales, is President of the Republic he is obliged by the international community to reduce the amount of land under coca cultivation. To do this President Morales has had to rhetorically pull coca leaf apart from Andean tradition. This presents a challenge to the integrity of indigenous-peasant based movements in the Chapare because it brings attention to their constructed nature and thus questions the authenticity of the 'originario' identity.

Keywords: Coca, Chapare, Bolivia, identity, indigenous, Originario 
Grisaffi, T. (2010) ' 'We are Originarios... We just aren't from here': Coca leaf and Identity Politics in the Chapare, Bolivia'. Bulletin of Latin American Research, 29:4, 425-439. http://onlinelibrary.wiley.com/doi/10.1111/j.1470-

9856.2010.00385.x/abstract

In early August 2006 I attended the anniversary of San Antonio, a village located in a tropical colonisation zone called the Chapare in the department of Cochabamba, Bolivia. The region is home to highland settlers but also to a handful of lowland indigenous groups including the Trinitarios and Yuracares. The anniversary of San Antonio was much like any other party that I had attended in the Chapare. There was a football tournament, disco, communal meal and a competition to select the most beautiful 'Cholita' in the village (in the Chapare 'Cholita' is a term used to describe single, young women who wear traditional highland clothes). Unlike other parties that I had attended in the tropics, the village also held a competition to choose the Reina de la Selva (Queen of the Jungle). The reason for this additional category was because several Yuracare families lived in the village.

Three rounds based on beauty, dress and speeches succeeded in whittling down the competition to one 'Cholita Queen' and one 'Jungle Queen'. The two girls stood next to each other on the wooden stage. The Cholita Queen wore a beautiful pollera (a layered gathered skirt), with a white blouse and gold earrings. Meanwhile the Jungle Queen wore a leopard print skirt and top with yellow tassels, face paint and long red feathers in her hair. Two hundred people looked on enthralled by the spectacle. The host, a peasant union leader called Doña Maria, asked both of the competitors a series of questions. The Cholita Queen was asked about the kind of food she enjoyed, national politics and highland music. The Jungle Queen on the other hand was required to confirm her knowledge of wild plants and animals native to the area. Maria politely enquired if the Jungle Queen might demonstrate her bow. With lightening speed the young girl pulled an arrow out of her quiver, and placed it on to the string, which she pulled taught. The Jungle Queen struck a magnificent pose with her bow pointing high in the air. The audience responded with delight, people pushed forward to get a glimpse and to take photos. 
Grisaffi, T. (2010) ' 'We are Originarios... We just aren't from here': Coca leaf and Identity Politics in the Chapare, Bolivia'. Bulletin of Latin American Research, 29:4, 425-439. http://onlinelibrary.wiley.com/doi/10.1111/j.1470-

The final round, which would determine the winner, was a dance off. Chicha Cumbia music blasted out of the sound system. The Cholita Queen shifted from foot to foot in a rather unenthusiastic Zapateo (stomp dance). The Jungle Queen meanwhile danced with far more energy. She brandished the bow above her head. The Jungle Queen's polyester outfit drew some criticism from the crowd however. One woman who was stood near to me complained that the Jungle Queen should have worn banana leaves because 'it would have been more authentic'. It was a tough decision for the judges to make but in the end the Jungle Queen won the tiara and sceptre.

During the event I was sat with a man from the village called Don Ramiro. We got talking about the differences between the lowland indigenous groups and the highland colonisers resident in the Chapare. Ramiro turned to me and said '...You know the real first peoples here were the Yuras...' he nodded in the direction of the Jungle Queen '...Most of them ran away into the jungle but some of them have become civilised already. They didn't want to give up their lands... but we conquered them with alcohol, cigarettes and salt'. I asked Ramiro '...But if the Yuracares really are the 'true first people here', then what does that make the colonisers?' Ramiro reflected with some uncertainty, '...well of course we are originarios (first people) ... we just aren't from here'.

I was intrigued by Ramiro's comment because it totally disrupts the idea of what being indigenous is all about. Ultimately being indigenous means nothing more than being from a place. Ramiro meanwhile was claiming to be a 'native', but native to somewhere else. The following day I was planting maize with my host family; eager to get to the bottom of this issue I asked the father, Don Alfonso, if he was indigenous. He told me, 'we are not indigenous; we don't all live in the countryside. We are workers, we work in the cities. For example Sabastian (Alfonso's son) is now a professional; he is not going to accept being indigenous. Not even we (Alfonso and his wife) are indigenous'. Don Alfonso's reaction to my question surprised me somewhat. Alfonso 
Grisaffi, T. (2010) ' 'We are Originarios... We just aren't from here': Coca leaf and Identity Politics in the Chapare, Bolivia'. Bulletin of Latin American Research, 29:4, 425-439. http://onlinelibrary.wiley.com/doi/10.1111/j.1470-

9856.2010.00385.x/abstract

had always spoken of himself as the proud descendant of the pre-conquest Nación Quechua (Quechua nation). What I had not previously realised was that he obviously saw himself as being not only different from, but also superior to the 'pueblito Indigena' (lowland indigenous groups).

In the hands of the Chapare colonisers 'culture' represents a powerful political tool. The Chapare peasant union presents a reified unitary culture built on the idea of the primordial difference of the 'originario' population. The colonisers make claims alluding to their rooted and enduring presence, they minimise the impact of Europeans and they assert their inalienable right to cultivate coca leaf because they are 'originarios' . However, while members of the peasant union play up to the idea that they are 'first peoples', in point of fact it is only relatively recently that they have reclaimed the ethnic dimension of their identity (García et al., 2004). More to the point, as the example above shows, the colonisers are very careful not to present themselves as being too indigenous which, as far as they are concerned, implies being backwards, illiterate and dirty.

The analytical challenge that the colonisers present to the anthropologist then, is the way that they see indigenous culture as belonging to them; homogenous, bounded and totally different from the Hispanic population. This is problematic because we cannot simply talk of a bipolar struggle between the dominant urban society on the one hand and pure indigenous people on the other (Abercrombie, 1991). Indigenous movements are not rigid; rather they draw on discourses, resources and support from a wide variety of sources. It is important in which case to interrogate the political and discursive processes that contribute to their formation (Rappaport, 2005).

In this article I argue that it was by no means inevitable that the Chapare colonisers would mobilise around indigenous cultural difference in order to justify their oppositional politics. Rather, here I describe how as class based identities have lost traction, the colonisers have knitted trade union politics together with an explicit indigenous project. However, unlike many groups

\footnotetext{
${ }^{1}$ It is beyond the scope of this article to consider the different ways that other organisations such as the Consejo Nacional de Markas y Ayllus del Qullasuyu (CONAMAQ), and the Confederación Indígena del Oriente Boliviano (CIDOB) use the term 'originario'.
} 
Grisaffi, T. (2010) ' 'We are Originarios... We just aren't from here': Coca leaf and Identity Politics in the Chapare, Bolivia'. Bulletin of Latin American Research, 29:4, 425-439. http://onlinelibrary.wiley.com/doi/10.1111/j.1470-

9856.2010.00385.x/abstract

studied by anthropologists, the Chapare peasants have never mentioned blood and soil, extended residence, ancestors, nor have they begun to wear feathers in their hair in order to defend their interests (Kuper, 2003). Instead I show how the Chapare peasant union has torn up what Bruno Latour (1993) refers to as the 'modern constitution' (the set of principals that separate out nature from culture), held up the coca leaf and filled it with social relations, history and culture. In so doing they have bought non-human actors to bear on the economic and political realm. By delegating responsibilities to the millenarian hoja sagrada (sacred leaf) the coca growers do not have to be forever present doing indigenous things, because conveniently the coca leaf stands in for the people concerned.

I argue that as a script for identity, coca leaf stands for the continuity and coherence of key concepts, such as sovereignty, nation and indigenousness. It is without doubt the perfect empty signifier (Laclau, 2005). However I also show how complications arose once the Chapare peasant union entered into elected office. In December 2005 Evo Morales, the leader of the Chapare coca growers' peasant union, won a landslide victory in Bolivia's presidential election. Today Evo Morales faces a dilemma, defending coca was fine while the coca growers were in opposition, but now that he is in the Presidential Palace he is obliged by the international community to stem the flow of cocaine to the US and Europe. From President Morales's point of view, coca leaf has gone from being a potent symbol of indigenous identity and anti-imperial resistance to something that has to be controlled. Now when Evo Morales goes back to the Chapare he no longer litters his speeches with phrases which justify coca, nor does he finish them with the phrase, 'Long live coca! Death to Yankees!' Instead he is much more likely to urge the rank and file to stop planting coca because as he himself frequently points out, it is all going to the drug industry. In this way and in a reverse of his previous strategy, Evo Morales tears the coca leaf apart from Andean tradition in order to justify the uprooting of coca plantations by the military. I argue that this 
Grisaffi, T. (2010) ' 'We are Originarios... We just aren't from here': Coca leaf and Identity Politics in the Chapare, Bolivia'. Bulletin of Latin American Research, 29:4, 425-439. http://onlinelibrary.wiley.com/doi/10.1111/j.1470-

9856.2010.00385.x/abstract

presents a challenge to the integrity of indigenous-peasant based movements in the Chapare because it calls attention to their constructed and fragile nature and thus questions the authenticity of the 'originario' identity. As Don Leonardo, a local coca union leader once told me, 'thanks to coca we are in power, but coca could also bring this government down'.

\section{The Rise of Indigenous Movements in Bolivia}

Over the past twenty years there has been a resurgence of Indian Movements and a self-conscious indigenous politics right across highland Latin America. A striking feature of these movements has been the ways that indigenous issues have been linked to resistance to globalisation and neoliberalism (Stavenhagen, 2002). In Bolivia it was the Chapare coca growers who were at the forefront of protests against the neoliberal state.

Neoliberal policies have wreaked havoc on the livelihoods of workers and peasants in Latin America. Herbert Klein explains that in the Pre-Morales era Bolivia was marked by enduring poverty, inequality and economic retardation (Klein, 2003: 254-256). Unemployment was on the rise and public services dwindled to the extent that the state did not adequately fulfill even its most basic functions (Gill, 2000). These poor indicators prompted observers to argue that as a result of neoliberal policies, 'the challenges of everyday life in Bolivia are dramatic and growing' (Arze and Kruse, 2004: 27).

Throughout the period 2000 to 2005 the unpopularity of the neoliberal model was clearly demonstrated by pitched battles in city streets over the privatisation of water, gas, and the IMF's imposition of an exorbitant income tax. The social movements that emerged to contest the neoliberal development model represented a broad coalition including, teachers, workers, students, pensioners, urban popular social sectors, indigenous groups and peasants. Despite the fact that 
Grisaffi, T. (2010) ' 'We are Originarios... We just aren't from here': Coca leaf and Identity Politics in the Chapare, Bolivia'. Bulletin of Latin American Research, 29:4, 425-439. http://onlinelibrary.wiley.com/doi/10.1111/j.1470-

9856.2010.00385.x/abstract

some of these sectors had urban and even lower middle class origins, they articulated themselves around indigenous symbols such as the Wiphala (the Andean flag of the first peoples) and coca leaf.

Scholars have noted that over the past ten years there has been an explosion of cultural affirmation in Bolivian society at large with increasing numbers of people reclaiming an indigenous heritage (Albo, 2008). This cannot simply be put down to the durability of Andean culture, but has to be seen as part of a broader reaction to the deeply unpopular neoliberal policies imposed on Bolivia from the outside. Andrew Canessa (2006) explains that the leaders of Bolivia's social movements sought to encourage the bases to identify themselves not only along class lines, but also as having a shared historical experience of oppression at the hands of an ethnically different elite group. Canessa notes that Evo Morlaes was particularly adept at tying together class and ethnicity in order to recast national political issues as 'indigenous issues'. The term 'originario' has become a post-colonial identity that has allowed Bolivia's social movements to overcome previous disunity along, racial, class, community and ethnic lines (see Albro, 2006).

The point of this article is to show how and why poor peasants in the Chapare became increasingly willing to assume an indigenous identity. I explain that as the neo-liberal state made efforts to forcibly eradicate coca leaf under the rubric of the 'War on Drugs' the Chapare colonisers defended their right to cultivate the crop through a cultural position. Coca union leaders such as Evo Morales emphasised the ethnic dimension inherent in the coca plant. I suggest that coca leaf can stand in for indigeneity and means that the Chapare colonisers themselves do not have to do indigeneity. The coca growers attain their 'indigenous' status by association with the coca leaf. However, I also point out that no matter how good coca leaf is at buoying up an ethno-nationalist project the presence of illegal coca-cocaine constantly threatens to destabilise the legitimacy of the emergent originario identity in the Chapare. 
Grisaffi, T. (2010) ' 'We are Originarios... We just aren't from here': Coca leaf and Identity Politics in the Chapare, Bolivia'. Bulletin of Latin American Research, 29:4, 425-439. http://onlinelibrary.wiley.com/doi/10.1111/j.1470-

\section{The Chapare Coca Growers}

Evo's Movimiento Al Socialismo (MAS) party has its roots in the peasants' organisations situated at the eastern foot of the Andes in the department of Cochabamba. The area known as the Chapare encompasses some 6000 square kilometres of dense tropical rainforest. In the mid 1970s coca cultivation started to spread throughout the region which was stimulated by the rising demand for cocaine in the US and Europe. At the height of the so called 'coca boom' the price of one hundred pounds of coca reached $\$ 800$ dollars, correspondingly coca cultivation in the Chapare leapt from an estimated 13,000 hectares in 1978 to 55,000 hectares only one decade later (Painter, 1994: 15). This in turn prompted a mad rush to the region. The population exploded from 24,000 in 1967 to an estimated 350,000 in 1989 (Perez, 1992: 28).

The majority of the early settlers in the Chapare were Quechua speaking peasants from the department of Cochabamba who, despite the later waves of colonists, still make up the majority of the population of the Chapare today. It is interesting to note that historians have characterised the Cochabamba peasants as de-Indianised penny capitalists when compared to Aymaras and Quechuas in the rest of the country. That is, as having a class identity rather than an indigenous one (Larson, 1998: 322-390, Rivera, 1987: 150). In the mid 1980s ex-miners and factory workers who had previously been strongly engaged with unions and provincial urban life in the highlands also migrated to the region.

The Chapare settlers point out that poverty, lack of land and employment in their points of origin, forced them to move to the tropical colonisation zone. The process of pauperisation in the highlands was a direct result of externally imposed structural adjustment policies that closed down 
Grisaffi, T. (2010) ' 'We are Originarios... We just aren't from here': Coca leaf and Identity Politics in the Chapare, Bolivia'. Bulletin of Latin American Research, 29:4, 425-439. http://onlinelibrary.wiley.com/doi/10.1111/j.1470-

9856.2010.00385.x/abstract

nationally owned mines and factories and allowed cheap foreign agricultural imports to flood the domestic market which hammered the peasantry.

The colonisers are dedicated to the cultivation of coca leaf, a perennial shrub native to the Andean region. Coca leaf has been consumed in the Andes since time immemorial, it can be chewed or prepared as a tea and is used in order to overcome fatigue, hunger and thirst. Coca leaf generates higher returns per hectare than any other crop and therefore forms the basis of peasant livelihood strategies.

Coca leaf appears to be a miracle plant for both consumers and producers; however there is a downside, coca leaf is also the raw material necessary to process cocaine. In 1988 Washington policy makers shifted the emphasis of anti-drugs programs away from cocaine interdiction to the forced eradication of coca leaf itself, thus turning the Bolivian coca farmers into the 'enemy of the war on drugs' (Albo, 2002: 75). In Bolivia the most significant piece of legislation in this respect is the draconian 'law 1008', which has victimised the poor and opened up new spaces for police corruption (Farthing, 1997). Law 1008 was passed by the Bolivian congress at the behest of US policy makers.

The military's efforts to forcibly uproot coca plantations have not only been ineffective but have resulted in violent confrontations with peasants. The troops responsible for coca eradication have been implicated in the torture, robbery, murder and rape of civilians (Ledebur, 2005). In the absence of any realistic alternative source of income and the failure of successive crop substitution programs (Farthing and Kohl, 2005) the coca growers have fought to maintain the right to grow coca. The Chapare peasants have asserted their right to farm this product based on cultural arguments and through union and political action.

\section{The Cultural Significance of Coca in the Chapare}


Grisaffi, T. (2010) ' 'We are Originarios... We just aren't from here': Coca leaf and Identity Politics in the Chapare, Bolivia'. Bulletin of Latin American Research, 29:4, 425-439. http://onlinelibrary.wiley.com/doi/10.1111/j.1470-

In the Andean highlands sharing and masticating coca is one of the most important markers of identity and is essential for the maintenance of good social relations (Allen, 1988). Similarly in the Chapare chewing coca is a very social activity indeed, to decline an offer to share coca would be to reject an invitation to be social. However, unlike in the highlands, in the Chapare there are no elaborate rituals that accompany the act.

During the twenty months that I conducted fieldwork in the Chapare I spent most evenings at home watching soap operas on the television and chewing coca leaf with Don Alfonso and his wife Doña Yolanda. The distribution of coca leaf involved nothing more than Doña Yolanda putting a large plastic bag full of coca leaf on the edge of her bed and declaring 'help yourself!' We would sit for a couple of hours munching away and smoking cigarettes. Doña Yolanda would make comments about the taste of the coca. If the coca was sweet then that was a good sign, if it was bitter then it meant that something bad was on the horizon.

In certain contexts coca can act as an essential mediator between human and spiritual worlds. This was vividly demonstrated to me when Doña Yolanda fell ill. One day she began to suffer from a bad stomach, constant hiccups, uncontrollable vomiting, and blurred vision. Yolanda was referred to a hospital in the city of Cochabamba where the doctors diagnosed that she was suffering from complications arising from diabetes. After two weeks Doña Yolanda was showing no signs of improvement. She became disillusioned at the cost and ineffectiveness of the medical treatment she was receiving and so she discharged herself. I urged Doña Yolanda to return to the hospital and I even offered to pay the bills for her, but she would hear none of it. Instead she spent the following three weeks at home in bed. Luckily Sabastian (Doña Yolanda's son) managed to slip out of his university course in Cochabamba to visit for a few days. Sabastian decided to contract a local Yatiri (traditional healer) to discover what the problem really was. 
Grisaffi, T. (2010) ' 'We are Originarios... We just aren't from here': Coca leaf and Identity Politics in the Chapare, Bolivia'. Bulletin of Latin American Research, 29:4, 425-439. http:/ / onlinelibrary.wiley.com/doi/10.1111/j.1470-

9856.2010.00385.x/abstract

The Yatiri was a middle-aged woman who lived nearby. The first night the Yatiri came to the house she placed a bag of coca leaves on Doña Yolanda's head. The following morning Sabastian removed the leaves from underneath his mother's woolly bobble hat and took them to the Yatiri's house. The Yatiri cast the leaves on to the ground and read them. She informed us that the earth was angry because four years ago, when Yolanda had a brief flirtation with an evangelical group, she stopped making monthly burnt offerings (known as a $Q^{\prime}$ owa) to the earth. During this period the land had continued to give her good harvests every year without fail. The result of this oversight was that the earth now wanted its payback and had taken Doña Yolanda's anima (soul/spirit). The Yatiri told us that the only way that Doña Yolanda would get better was if a 'limpieza' (ritual cleansing) was performed. That night we carried Doña Yolanda to the place where her soul had been lost. A small group of family and friends spent the night performing a Q'owa, all the while chewing coca and calling Doña Yolanda's anima back to her. The following day Doña Yolanda was returned to her bed. Again coca leaves were placed on her head for one night, which were then read by the Yatiri who was able to confirm that the 'limpieza' had been successful. Remarkably two days later Doña Yolanda got out of bed and walked around the house for the first time in more than a month. After one week she was putting on weight and soon returned to work in the fields. Doña Yolanda considered that she was cured because of the actions taken by the Yatiri. Despite her belief in the efficacy of the Yatiri it is worth bearing in mind that during the entire episode she had continued to take the medication that the hospital had given to her.

\section{The Traditional/Non-Traditional Distinction}

In 1961 the then President of Bolivia, Victor Paz Estenesoro, signed the United Nations single convention on narcotic drugs in Vienna. This document established that 'the parties shall so far as 
Grisaffi, T. (2010) ' 'We are Originarios... We just aren't from here': Coca leaf and Identity Politics in the Chapare, Bolivia'. Bulletin of Latin American Research, 29:4, 425-439. http://onlinelibrary.wiley.com/doi/10.1111/j.1470-

9856.2010.00385.x/abstract

possible enforce the uprooting of all coca bushes which grow wild. They shall destroy the coca bushes if illegally cultivated,' and, 'coca leaf chewing must be abolished within twenty-five years' (Metaal et al., 2006). However, given the cultural significance attached to coca in Bolivia, lawmakers were required to permit limited coca leaf production to supply the domestic traditional market. Anti-drug law 1008 dictates that twelve thousand hectares of coca can be legally cultivated in designated 'traditional growing zones'. These are the Yungas of Vandiola in the department of Cochabamba, where two hundred hectares are permitted, and the rest is in the Yungas of La Paz. Under Law 1008 coca cultivation anywhere outside of these areas, including that in the Chapare, was outlawed and subject to systematic eradication over the coming years (Ledebur and Youngers, 2006).

The Chapare coca growers have always considered the traditional/non-traditional distinction in Law 1008 to be arbitrary and deeply unfair. Nevertheless a comparison of these two coca-growing areas does highlight some significant differences. The coca growing zones in the Yungas valleys of La Paz and Cochabamba have a very different history to that of the Chapare. Over 1000 years ago Aymara civilisations were already cultivating coca leaf in the Yungas valleys (Conzelman, 2006). From her research in the Yungas of La Paz, Alison Spedding (1994) emphasises the importance of rituals that accompany labour in the fields and reciprocal modes of labour organisation, known as Ayni, as a means for the reproduction of social identities. Spedding goes as far to refer to the coca field as a 'total social fact' (Spedding, 1997).

Coca cultivation in the Chapare meanwhile is not underlain by the elaborate understandings and practices that Spedding discusses. In contrast to the care with which coca is grown in the Yungas, the Chapare crop is doused with fertiliser and pesticide, and when harvested it is ripped from the branches in great handfuls. Ayni meanwhile is disparagingly described as 'a thing that we did in the time of the indigenas', a reference to the Chapare peasants' origins in the 
Grisaffi, T. (2010) ' 'We are Originarios... We just aren't from here': Coca leaf and Identity Politics in the Chapare, Bolivia'. Bulletin of Latin American Research, 29:4, 425-439. http://onlinelibrary.wiley.com/doi/10.1111/j.1470-

9856.2010.00385.x/abstract

highlands. What is more, most people are unwilling to disclose the location of their coca plantations to neighbours because of the danger that they might denounce them to the police. As a result Ayni is an almost impossible form of labour relation in the Chapare.

As we have seen, colonisers do chew Chapare coca and it can be used for ritual and medicinal purposes. However, even the Chapare colonisers see Yungas coca as being of a higher quality, and somehow more 'traditional' than their crop. Take for example the case of Don Angel, a good friend of mine who lived twenty minutes from my house in the Chapare. Don Angel's main occupation was to buy coca leaf and then divert it to the artesian cocaine processing factories located deep in the jungle. As a result he always had huge quantities of coca leaf at his house. He would never touch any of it though. Don Angel would only ever chew Yungas' coca because the small, sweet, green Yungas leaves are far better to chew. He told me that the majority of the large, thick, thora (marked) and bitter leaves from the Chapare go directly to the maceration pits to be transformed into cocaine. The difference in quality is reflected in the price; a pound of Yungas' coca costs almost twice as much as Chapare coca.

\section{The Politicisation of the Sacred Coca Leaf}

In 1988 impending anti-narcotics legislation (law 1008) threatened to outlaw coca plantations in the Chapare. This spelled disaster for the peasant colonisers as coca represented the only crop which gave them a reasonable return and allowed them to subsist. The fight to defend the right to grow a crop associated with the international drugs industry was never going to be an easy one. The Chapare colonisers' status as an uprooted multicultural population meant that they were unable to claim any cultural heritage as 'traditional coca cultivators' in the way that Yungas coca growers could. The Chapare coca union sidestepped the issue by focusing its attention on the coca leaf itself. Coca leaf went from being something that had previously been totally irrelevant for 
Grisaffi, T. (2010) ' 'We are Originarios... We just aren't from here': Coca leaf and Identity Politics in the Chapare, Bolivia'. Bulletin of Latin American Research, 29:4, 425-439. http://onlinelibrary.wiley.com/doi/10.1111/j.1470-

9856.2010.00385.x/abstract

public self-identification, no different from any other crop they grew, like oranges, rice or bananas, to become coca milenaria (millennial coca), absolutely entwined with the presentation of what had now become vocal 'originarios' (García et al., 2004: 438-442).

In the 1993 Macchu Pichu manifesto, a document elaborated by the Council for the Defence of Coca Producers of which Evo Morales was then President, it is stated that:

'The eradication of the coca leaf would be, for our Andean people, the death. Because for us coca is everything: Our material survival, our myths, our cosmovision of the world, the happiness to live, the word of our ancestors, the constant dialog with the Pachamama, our reason to be in this world. In sum, the fight for the revaluation and defence of the coca leaf synthesises all of these demands that today give meaning to our lives and without which there will be no future. It is the symbol and the representation of our identity' (CAPC 1993: my emphasis).

In order to make the sacred status of coca leaf explicit to the wider world the Chapare agricultural federations have organised events such as coca chew-ins, folkloric music festivals, and coca fairs in the cities (Healy, 1991). Members of the coca union undertake public rituals in which coca plays a highly visible role, award garlands of coca to visiting dignitaries, and the coca federation has even run courses in the Chapare on how to cook with coca.

Within the Chapare the coca union's radio station has been absolutely essential in promoting the idea that coca is sacred and for this reason should be defended. A mural painted on the wall of the radio station summarises the editorial line well. It depicts an old man wearing a ch'ulo (traditional Andean hat), his check bulging with coca, beneath is written a proverb '...For 
Grisaffi, T. (2010) ' 'We are Originarios... We just aren't from here': Coca leaf and Identity Politics in the Chapare, Bolivia'. Bulletin of Latin American Research, 29:4, 425-439. http://onlinelibrary.wiley.com/doi/10.1111/j.1470-

9856.2010.00385.x/abstract

us the coca leaf is the culture of our ancestors... to them it causes insanity and idiocy'. The DJs at the radio station broadcast national music. The lyrics of many of these songs refer to coca and indigenous culture (Bigenho, 1998) and the union leaders and reporters that speak on the radio reiterate a standard message. These interlocutors place the Chapare within its global context. They point out how unjust it is that their native coca has been eradicated by troops serving foreign interests. They explain that coca is sacred and is definitely not cocaine. If only it was legal, they say, then the rest of the world would also be able to benefit from this special leaf. The cumulative effect of repeating the same message over and over again on the radio and at union meetings is that the coca union has a strong overarching ideology built around the monumentalisation of coca.

Mobilising under the banner of coca meant that unlike previous ethnic movements in the Aymara Altiplano, which had very limited appeal (Albo, 1987: 409), the coca union was able to project a more flexible indigenous lite version of identity. The coca growers could now support an ethno-nationalist project without actually having to be all that indigenous themselves. What is more, by articulating the Chapare peasants' commercial concerns with a broader cultural and ethnic-nationalist dimension, sacred coca has offered the coca union a moral justification, allowing it to reach out and form alliances with other social sectors across the country (García et al., 2004).

\section{Disrupting Identities}

So far I have argued that coca became the perfect 'empty signifier' (Laclau, 2005), successfully overlaying the patchwork of migrant identities and allowing the peasants to forge a coherent and solid movement within the Chapare. However while the defence of 'sacred' coca gave the Chapare 
Grisaffi, T. (2010) ' 'We are Originarios... We just aren't from here': Coca leaf and Identity Politics in the Chapare, Bolivia'. Bulletin of Latin American Research, 29:4, 425-439. http://onlinelibrary.wiley.com/doi/10.1111/j.1470-

9856.2010.00385.x/abstract

peasants a common cause with fellow colonisers, today the issue of illegal coca threatens to destabilise the legitimacy of the emerging originario identity.

I argue that the ability of coca to stand in for the indigenous status of the Chapare colonisers is becoming increasingly tenuous. This is because today the MAS government has to control coca production. Coca union leaders such as Evo Morales have had to admit that some coca is illegal and therefore should be eradicated. What is more, it is not only the political leadership that explicitly acknowledges the link between coca and cocaine. The Chapare peasants routinely portray coca leaf produced in other regions as being only fit for the maceration pit. My aim in this section is to consider the legacy of the complex entanglement of the legal and cultural definitions of coca leaf and the impact that this has had on identity politics in the Chapare.

Once in the Palacio Quemado (Presidential Palace) President Evo Morales (who continues in his role as the leader of the Chapare coca growers union) had to come up with a realistic strategy so that Bolivia would not become the predicted 'narco-state'. To this end he opted to extend an agreement that had been made in October 2004 between the coca growers and the then president of Bolivia, Carlos Mesa. This policy allows each coca union member to grow a limited amount of coca known as a cato. A cato is an area covering 1600 square meters, which provides an income in the range of $\$ 70$ to $\$ 100$ dollars a month. President Morales also increased the area of coca that could be legally grown from 12,000 to 20,000 hectares nationally. Under the new regime only 3,500 hectares of coca can be grown in the Chapare. In return for this, the coca union agreed to co-operate in reducing any coca excess to the one-cato limit, to collaborate in the fight against drug trafficking, and to allow coca eradication in the Carrasco and Isiboro national parks, both of which are located in the Tropics of Cochabamba (Ledebur and Youngers, 2006).

The one cato policy has been successful from the perspective of the Chapare coca growers who consider the instability and violence provoked by forced coca eradication as a thing of the 
Grisaffi, T. (2010) ' 'We are Originarios... We just aren't from here': Coca leaf and Identity Politics in the Chapare, Bolivia'. Bulletin of Latin American Research, 29:4, 425-439. http://onlinelibrary.wiley.com/doi/10.1111/j.1470-

9856.2010.00385.x/abstract

past. What is more, analysis from the Andean Information Network suggests that cooperative reduction may prove to be more successful at containing coca production in the long term than the previous strategy of forced eradication (Ledebur and Youngers, 2006).

However anecdotal evidence does suggest that not all coca growers are sticking to the new regime. One day while I was accompanying Don José, a prominent coca union leader, he told me in hushed tones, 'it's true, with the cato it (the price of coca) has gone up, but still people miss it. Before... a person would have three, four or five hectares of coca and some are even complaining now! They can’t accept just one cato and they say Evo ‘que cujodo eres!'(what an idiot you are!) Some people don't even have a cato just half a cato or none at all, others well they still have three hectares, but they hide it 'adentro' (deep in the jungle).

The relationship between the MAS government and the coca growers in regions such as the Yungas of La Paz and the Yungas de Vandiola is quite different to that of the coca growers in the Chapare. While the Chapare coca growers have always called for the legalisation of coca, coca in the Yungas zones always was legal under law 1008. In the past farmers in the Yungas region were permitted to grow several hectares of coca.

Evo's proposal that there should be only one cato of coca per affiliate was to be extended to the 'traditional' areas as well, thereby dramatically reducing the amount of coca that Yungas cultivators can grow. This has seriously damaged Evo's popularity in the Yungas, and in the 2005 presidential elections Yungas coca growers voted for the right-winger Jorge Quiroga, who vowed to continue forced coca eradication in the rival area of the Chapare (Conzelman, 2006).

Evo sent in government troops to the Yungas de Vandiola region to uproot coca bushes in September 2006. The local population attempted to block the security forces from entering what they claimed was a traditional coca growing area and in the disturbance that followed two peasants were shot and killed. The following dialogue is taken from a video recorded by the human rights 
Grisaffi, T. (2010) ' 'We are Originarios... We just aren't from here': Coca leaf and Identity Politics in the Chapare, Bolivia'. Bulletin of Latin American Research, 29:4, 425-439. http://onlinelibrary.wiley.com/doi/10.1111/j.1470-

ombudsman the day after the massacre. In the video the peasants stress that they are not at all like their Chapare counterparts but are proper natives.

Ombudsman: Where are you located? Are you in the Carrasco National Park comrades?

Crowd: NO!!!

Man 1: We are in the traditional zone, we are in Antahuacana comrades, we are not in the park. We are natives. We live here we are not Chapareños

Ombudsman: Is there a foreigner amongst you comrades?

Man 2: These are pure lies, saying that there are Peruvians and Colombians here, nothing Señor.

Man 3: All of us are Bolivians

Man 4: If they say that we are foreigners, let them identify us with documents, all of us are Bolivians! ${ }^{2}$

While the Vandiola peasants claimed that this was an unprovoked attack, the military maintained that the peasants ambushed them with help from the mafia. Evo's administration accepted this account and challenged the peasants' claim to authenticity which weakened both their claim to legitimacy and their power (Opinión, 2006).

During this period the Chapare coca union's radio station broadcast negative messages about the Yungas de Vandiola. In his morning program the director of the radio station, Don Rodrigo, took to calling the Yungas peasants 'drug traffickers'. In the afternoon broadcast the reporter for the station, Don Simón, ranted against the Vandiola peasants, saying: 'the laziest has three hectares, but some have sixteen hectares! Imagine what that would be worth? With that kind

\footnotetext{
2 This material was given to me by Kathryn Ledebur of the Andean Information Network in Cochabamba, Bolivia
} 
Grisaffi, T. (2010) ' 'We are Originarios... We just aren't from here': Coca leaf and Identity Politics in the Chapare, Bolivia'. Bulletin of Latin American Research, 29:4, 425-439. http://onlinelibrary.wiley.com/doi/10.1111/j.1470-

9856.2010.00385.x/abstract

of money I would probably go crazy...they have never fought for the cato, they just sat there quietly while we suffered, turning their coca into mamita Dolares, (money) you know? The white factory! But now their coca is being eradicated, they don't like it and they claim it is a traditional area!'

The radio station's broadcasts continued with this firm tone for a couple of weeks. One day an old peasant dressed in a football shirt and torn trousers held up by a piece of string dropped a letter off at the station. Gerardo, the station secretary, tore it open, his eyes lit up and he shook his head. The letter contained the resolutions of an extraordinary general meeting of the local peasant union in the Yungas de Vandiola (where the two peasants had been shot by the military). In the letter it was stated that the union affiliates were 'indigenous' to the Vandiola region and should therefore be allowed to grow unlimited coca. The document was signed 'Comandante Emilio'. Gerardo read the letter out loud to Don Rodrigo and Don Simón, he concluded, 'Pah! They are nothing but 'peasants'. By this he meant they are not real 'originarios' who should be accorded special rights.

The following day I was at home helping Don Alfonso pack the dried coca into fifty-pound sacks to be sold at market. Alfonso was up to his waist in the sack jumping up and down on the coca to compress it. He lamented 'look how green and flat the coca is... how can anyone demonise this leaf?' As we worked we listened to Don Rodrigo's breakfast show. Rodrigo based his entire radio show around the contents of the letter that had arrived at the station the previous day. Rodrigo ratcheted up the tensions through a process of othering the Yungas peasants. Rodrigo postulated that the only reason the letter was signed 'Comandante Emilio' was because the Vandiola peasants had a guerrilla force. 'If that is so...' Don Rodrigo asserted '...then the military were right to go in there to sort them out!' Don Alfonso nodded in agreement. 'They are not real Cocaleros' Alfonso told me, 'why not?' I asked. 'Well, because they are not organised like we are. 
Grisaffi, T. (2010) ' 'We are Originarios... We just aren't from here': Coca leaf and Identity Politics in the Chapare, Bolivia'. Bulletin of Latin American Research, 29:4, 425-439. http://onlinelibrary.wiley.com/doi/10.1111/j.1470-

9856.2010.00385.x/abstract

Vandiola is at 'altura' (higher up) the coca in Vandiola can only be harvested once every six months and the leaves are far thicker, full of calories and alimentation. You can't chew that coca. It is only good for one thing, dancing on!' By this Alfonso was telling me that Vandiola coca goes directly to the maceration pit to be transformed into cocaine. Doña Yolanda, who was in the kitchen, put her head around the door. 'See what they do in Vandiola? It hurts me what they do with our poor little coca!'

In the example above we see that the coca union radio station portrayed the coca growers from the Yungas de Vandiola as 'drug traffickers'. In essence the Chapare coca growers took the same discourse that had been used against them for the past twenty years and turned it against their rivals. This process of 'othering' constitutes an attack against the Yungas coca growers' status as 'traditional coca cultivators'. The fact that the Chapare coca growers support anti-coca policies when they are carried out in rival regions clearly undermines their alleged unconditional commitment to the native shrub. In this context the claims made by the Chapare colonisers that they defend coca because it is 'the symbol and the representation of our identity' do appear to be rather hollow. This schism reveals the political and economic motivations behind the manipulated coca identity, namely that the Chapare coca growers present coca as 'native' and therefore untouchable in order to defend their economic interests.

\section{Conclusion}

The coca leaf produced in the Chapare has healing powers, it has ritual efficacy, but it is also an important commodity, which provides the bulk of the income for poor colonisers. The Chapare settlers themselves point out that the only reason they took up growing coca in the first place was because it was one of the few opportunities available which allowed them to survive the crisis that was provoked by neoliberal structural adjustment. The mobilisation of the coca leaf therefore cannot be considered to be unconscious nativism on the part of the colonisers. 
Grisaffi, T. (2010) ' 'We are Originarios... We just aren't from here': Coca leaf and Identity Politics in the Chapare, Bolivia'. Bulletin of Latin American Research, 29:4, 425-439. http://onlinelibrary.wiley.com/doi/10.1111/j.1470-

The fact that the Chapare colonisers have fore-grounded the indigenous dimension of coca leaf in order to make demands for inclusion, recognition and access to power does therefore appear to be an example of the so-called 'invention of tradition'. However, following Marisol De La Cadena (2007) I argue that indigenous politics have to be taken on their own terms. While it might appear to be an oxymoron within European canons, being an 'originario' coca grower is an identity that is actively assumed, emphasised and modified in relation to the prevailing conditions. What is more, the ethnic touch of the Chapare colonisers is intimately bound-up with the coca leaf, and while the symbol of coca leaf has been deployed in order to invoke an alternative Andean future, this symbol is not stable but is constantly recreated depending on the context and requirements of the ongoing struggle.

I do not see this as a phoney political project, however, because symbols can only ever acquire meaning when human-beings have something invested in them, and in this instance the people who are doing the inventing are the same Aymara and Quechua speakers that have suffered a long history of discrimination and oppression. For these reasons I see the revalorisation of coca leaf as an innovative and pragmatic response by those deemed to be non-persons by elite groups, which requires indigenous people to be connected to the past in ways that categorically exclude them from the domain of modern economics and politics. The deployment of coca leaf should therefore not be seen as merely 'reactive' (Ortner, 1995: 180), endowing poor people with some sort of undeserved indigenous value-added, but as a step towards the 'indigenisation of modernity' (Sahlins, 1999).

However the focus on coca has proved double-edged; it works as a unifier but it is also strongly connected in many national and international agendas to cocaine. This is especially the case in relation to the Chapare colonisers who produce coca leaf that goes to the cocaine trade. Coca can therefore make the cocaleros the victim of eradication campaigns, violence and the war on 
Grisaffi, T. (2010) ' 'We are Originarios... We just aren't from here': Coca leaf and Identity Politics in the Chapare, Bolivia'. Bulletin of Latin American Research, 29:4, 425-439. http://onlinelibrary.wiley.com/doi/10.1111/j.1470-

9856.2010.00385.x/abstract

drugs (and terror). The ambiguous status of coca is amplified by some cocaleros who publicly accuse other cocaleros (in the Chapare or in other more 'traditional' coca growing regions such as the Yungas) of growing coca for the drug trade.

Just as in the past enemies of the coca growers have tried to pull coca leaf apart from notions of tradition in order to undermine the relevance of sectarian demands, so Evo's administration has also made efforts to pull down this troublesome 'empty signifier'. Since Evo Morales assumed power he has ceased to monumentalise the sacred coca leaf and as a result this nodal point around which diverse groups could coalesce is beginning to dissolve. This case clearly shows the fragility of any kind of alternative hegemonic position and the tragedy of Latin American radical politics. Evo Morales is effectively caught in some of the same dilemmas faced by previous reactionary governments.

Acknowledgements I would like to gratefully acknowledge the support of the Economic and Social Research Council. I would also like to thank Prof P. Harvey, Prof J. Gledhill, Dr M. Bolton, H. Brown and Dr R. Sanchez who have read previous versions of this article.

\section{References}

Abercrombie, T. (1991) 'To be Indian, to be Bolivian: Ethnic and National Discourses of Identity' in G. Urban and J. Sherzer (eds.) Nation-States and Indians in Latin America. University of Texas: Austin.

Albo, X. (1987) 'From MNRistas to Kataristas to Katari' in S. Stern (ed.) Resistance, Rebellion and Consciousness in the Andean Peasant World, 18th to 20th Centuries. University of Wisconsin: Madison.

Albo, X. (2002) Pueblos Indios en la política. CIPCA: La Paz. 
Grisaffi, T. (2010) ' 'We are Originarios... We just aren't from here': Coca leaf and Identity Politics in the Chapare, Bolivia'. Bulletin of Latin American Research, 29:4, 425-439. http://onlinelibrary.wiley.com/doi/10.1111/j.1470-

9856.2010.00385.x/abstract

Albo, X. (2008) 'The Long Memory of Ethnicity and Some Temporary Oscillations' in J. Crabtree and L. Whitehead (eds.) Unresolved Tensions: Bolivia Past and Present. University of Pittsburgh Press: Pittsburgh.

Albro, R. (2006) 'The Culture of Democracy and Bolivia's Indigenous Movements'. Critique of Anthropology 26(4): 387-410.

Allen, C. (1988) The Hold Life Has: Coca and Cultural Identity in an Andean Community. Smithsonian Institute Press: London.

Arze, C. and Kruse, T. (2004) 'The Consequences of Neoliberal Reform'. NACLA Report on the Americas 38(3): 23 - 28.

Bigenho, M. (1998) 'Coca as a Musical Trope of Bolivian Nation-ness'. Political and Legal Anthropology Review 21(1).

Canessa, A. (2006) "Todos Somos Indígenas': Towards a New Language of National Political Identity'. Bulletin of Latin American Research 25(2): 241-263.

CAPC (1993) 'Manifiesto de Macchu Picchu: Qosqo Perú', Consejo Permanente en Defensa de los Productores de Hoja de Coca en los Paises Andinos: La Paz: Bolivia.

Conzelman, C. (2006) 'El movimiento cocalero en los Yungas de Bolivia: diferenciación ideológica, económica y política' in N. Robins (ed.) Estudios Bolivianos volumen IV: conflictos políticos y movimientos sociales en Bolivia. Plural Editores: La Paz.

De La Cadena, M. (2007) 'Taking Indigenous Politics in its Own Terms Requires an Analysis Beyond Politics' Local Knowledge and State Form: Reflections on the Case Study in Comparative Research on the Modern State. University of Manchester.

Farthing (1997) 'Social Impacts Associated with Anti Drug Law 1008' in B. Léons and H. Sanabria (eds.) Coca, Cocaine, and the Bolivian Reality. State University of New York Press: Albany.

Farthing, L. and Kohl, B. (2005) 'Conflicting Agendas: The Politics of Development Aid in DrugProducing Areas'. Development Policy Review 23(2): 183-198.

García, A., Chávez, M. and Costas, P. (2004) Sociología de los movimientos sociales en Bolivia: estructuras de movilización, repertorios culturales y acción política. Diakonia, Oxfam: La Paz.

Gill, L. (2000) Teetering on the Rim: Global Restructuring, Daily Life and the Armed Retreat of the Bolivian State. Columbia University Press: New York. 
Grisaffi, T. (2010) ' 'We are Originarios... We just aren't from here': Coca leaf and Identity Politics in the Chapare, Bolivia'. Bulletin of Latin American Research, 29:4, 425-439. http://onlinelibrary.wiley.com/doi/10.1111/j.1470-

9856.2010.00385.x/abstract

Healy, K. (1991) 'Political Ascent of Bolivia's Peasant Coca Leaf Producers'. Journal of Inter American Studies and World Affairs 33(1): 87-121.

Klein, H. (2003) 'Social Change in Bolivia Since 1952' in M. Grindle and D. Pilar (eds.) Proclaiming Revolution: Bolivia in Comparative Perspective. Institute of Latin American Studies and David Rockefeller Center for Latin American Studies: London and Cambridge, MA.

Kuper, A. (2003) 'The Return of the Native'. Current Anthropology 44(3): 389-402.

Laclau, E. (2005) On Populist Reason. Verso: London and New York.

Larson, B. (1998) Cochabamba, 1550-1900: Colonialism and Agrarian Transformation in Bolivia. Duke University Press: Durham, NC.

Latour, B. (1993) We Have Never Been Modern. Harvester Wheatsheaf: London.

Ledebur, K. (2005) 'Bolivia: Clear Consequences' in C. Youngers and E. Rosin (eds.) Drugs and Democracy in Latin America: The Impact of U.S. Policy. Lynne Rienner: Boulder, London.

Ledebur, K. and Youngers, C. (2006) Crisis or Opportunity? Bolivian Drug Control Policy and the US Response. [WWW document]. URL http://www.wola.org/publications/AINWOLA\%20Drug\%20Policy\%20Memo\%20FINAL\%20brief.pdf [accessed 10 July 2006].

Metaal, P., Jelsma, M., Argandona, M., Soberon, R., Henman, A. and Echeverria, X. (2006) 'Coca Yes, Cocaine, No? Legal Options for the Coca Leaf', TNI Briefing Series. Transnational Institute: Amsterdam.

Opinión (2006) 'Gobierno sospecha que 'narcos' Colombianos operan en Carrasco', Opinión. Octubre 03: Cochabamba.

Ortner, S. (1995) 'Resistance and the Problem of Ethnographic Refusal'. Comparative Studies in Society and History, 37:1, 173-193.

Painter, J. (1994) Bolivia and Coca: A Study in Dependency. Lynne Rienner: Boulder; London.

Perez, C. (1992) 'Tendencias migratorias en las areas de producción de coca en Cochabamba, Bolivia ', in M. Roa (ed.) Drogas y sociedad: síntesis del seminario de Cochabamba del grupo CLACSO narcotráfico y sociedad. CERES/CLACSO Cochabamba.

Rappaport, J. (2005) Intercultural Utopias. Public Intellectuals, Cultural Experimentation and Ethnic Pluralism in Colombia. Duke University Press: Durham. 
Grisaffi, T. (2010) ' We are Originarios... We just aren't from here': Coca leaf and Identity Politics in the Chapare, Bolivia'. Bulletin of Latin American Research, 29:4, 425-439. http:// onlinelibrary.wiley.com/doi/10.1111/j.1470-

Rivera, S. (1987) Oppressed but not Defeated: Peasant Struggles among the Aymara and Quechua in Bolivia, 1900-1980. United Nations Research Institute for Social Development: Geneva.

Sahlins, M. (1999) 'Two or Three Things That I Know About Culture'. Journal of the Royal Anthropological Institute, 5:3, 399-421.

Spedding, A. (1994) Wachu wachu: cultivo de coca e identidad en los Yunkas de La Paz. Hisbol: La Paz.

Spedding, A. (1997) 'The Coca Field as a Total Social Fact', in B. Léons and H. Sanabria (eds.) Coca, Cocaine, and the Bolivian Reality. State University of New York Press.: Albany, NY.

Stavenhagen, R. (2002) The Return of the Native: The Indigenous Challenge in Latin America. ILAS Occasional Papers 27: London. 